\title{
Eletrophysiological study of the caudal nerve on developing rats ${ }^{1}$
}

\author{
Estudo eletrofisiológico do nervo caudal em ratos em desenvolvimento
}

\author{
Juliana Netto Maia', Celina Cordeiro de Carvalho"I, Marina Hazin Galvão ${ }^{\mathrm{III}}$, Anderson de Lima Silva"II, Ana Carine Gouveia \\ Mendes ${ }^{\mathrm{III}}$, Sílvia Regina Arruda de Moraes ${ }^{\mathrm{IV}}$, Otávio Gomes Lins ${ }^{\mathrm{V}}$ \\ ${ }^{\mathrm{I}}$ Fellow Master degree, Neuropsychiatry and Behavioural Sciences, UFPE, Pernambuco, Brazil. \\ ${ }^{\text {II } M a s t e r ~ i n ~ B i o p h y s i c, ~ F e l l o w ~ P h D ~ d e g r e e, ~ N e u r o p s y c h i a t r y ~ a n d ~ B e h a v i o u r a l ~ S c i e n c e s, ~ U F P E, ~ P e r n a m b u c o, ~ B r a z i l . ~}$

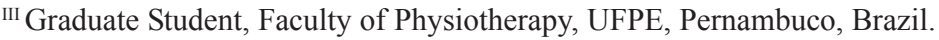 \\ IV Associate Professor, Department of Anatomy, UFPE, Pernambuco, Brazil. \\ ${ }^{v}$ Associate Professor, Department of Neuropsychiatry and Behavioural Sciences, UFPE, Pernambuco, Brazil.
}

\begin{abstract}
Purpose: To non-invasively study the sensory nerve conduction of the caudal nerve of normal developing rats. Methods: Twenty normal Wistar male rats served as subjects. Caudal nerve conduction studies were performed at 60 days from birth and weekly at end of six consecutive weeks. The caudal nerve was stimulated distally and nerve potentials were recorded proximally on the animal's tail using common "alligator" clips as surface electrodes. Results: The amplitude and the conduction velocity of the caudal nerve sensory action potential increased linearly from $29 \pm 6 \mu \mathrm{V}$ to $85 \pm 13 \mu \mathrm{V}$ and from $34 \pm 3 \mathrm{~m} / \mathrm{s}$ to $44 \pm 4 \mathrm{~m} / \mathrm{s}$, respectively, between the 8 th and the 15 th week of life. The equations of linear regressions were as followed: Amplitude $(\mu \mathrm{V})=8.1 \times$ weeks $-34\left(\mathrm{R}^{2}=0.99\right)$ and NCV $(\mathrm{m} / \mathrm{s})=1.2 \times$ weeks $+25\left(\mathrm{R}^{2}=0.86\right)$. Conclusions: It was possible to study non-invasively the sensitive conduction of the caudal nerve of normal developing rats and describe reference values. The technique and data may be used as animal model in physiological and pathological studies.
\end{abstract}

Key words: Neural Conduction. Electrodiagnosis. Rats.

\section{RESUMO}

Objetivo: Estudar de forma não invasiva a condução nervosa sensitiva do nervo caudal em ratos normais em desenvolvimento. Métodos: Vinte ratos machos Wistar foram utilizados. A conducão nervosa foi realizada a partir dos 60 dias, semanal durante seis semanas consecutivas. O nervo caudal foi estimulado distalmente, os potenciais foram registrados proximalmente na cauda do animal usando garras comum do tipo "jacaré" como eletrodos de superficie. Resultados: A amplitude do potencial de ação de nervo sensitivo a velocidade de condução nervosa do nervo caudal cresceu linearmente de $29 \pm 6 \mu \mathrm{V}$ para $85 \pm 13 \mu \mathrm{V}$ e de $34 \pm 3 \mathrm{~m} / \mathrm{s}$ para $44 \pm 4 \mathrm{~m} / \mathrm{s}$, respectivamente, entre a $8^{\circ}$ e a $15^{\circ}$ semana da vida do animal. As equações de regressão linear foram as seguintes: Amplitude $(\mu \mathrm{V})=8,1 \times$ semanas -34 $\left(\mathrm{R}^{2}=0,99\right)$ e velocidade de conducao nervosa $(\mathrm{m} / \mathrm{s})=1,2 \times$ semanas $+25\left(\mathrm{R}^{2}=0,86\right)$. Conclusões: Foi possível estudar de forma não invasiva a condução nervosa sensitiva do nervo caudal de ratos normais em desenvolvimento e descrever valores de referência. A técnica e os dados podem ser usados como modelo animal em estudos fisiológicos e patológicos.

Descritores: Condução Nervosa. Eletrodiagnóstico. Ratos.

${ }^{1}$ Research performed at Department of Anatomy, Post-Graduation Program in Neuropsychiatry and Behavioural Sciences, Federal University of Pernambuco (UFPE), Brazil.

\section{Introduction}

Electrophysiological conduction studies of peripheral nerves are often used in animal experimental models and human clinical assessments ${ }^{1}$. The caudal, saphenous, sural, sciatic, tibial, fibular and facial are the nerves most commonly accessed in animals ${ }^{2-5}$. The literature has described several methods of nerve conduction studies, including their respective reference values ${ }^{6,7}$.
The technique varies according to the nerve to be studied and the method used for stimulating the nerve and recording the potentials. When attached to the skin, surface electrodes allow a non-invasive assessment of the nerve. Invasive techniques consist of surgically placing electrodes or introducing thin needles inside the animal body ${ }^{7-10}$. 
The caudal nerve has been used for nerve conduction studies in rats, for being easily accessed and long, enabling accurate measurement of distances ${ }^{11,12}$. Some difficulties may arise in adjusting and fixating surface electrodes on the animal's relatively thin tail. There are not many electrophysiological studies on the rat caudal nerve during development. The objective of this work was to study electrophysiologically the rat caudal nerve during growth, using common "alligator" clips as stimulating and recording surface electrodes.

\section{Methods}

Twenty male 60 days of age albinos Wistar rats were studied. The animals were kept at the animal colony of the Department of Anatomy, Federal University of Pernambuco, under $25^{\circ} \mathrm{C}$ ambient temperature, $12 \mathrm{hr}$ light $/ 12 \mathrm{hr}$ dark photoperiod, in collective plastic cages (maximum 5 animal per cage), maintenance diet and water ad libitum. Nerve conduction studies were performed at the Electroneuromyography Laboratory of the Clinics Hospital, Department of Neuropsychiatry, Federal University of Pernambuco, during 8 consecutive weeks, once a week.

Six alligator clips were attached to a formicated board in straight line at 3 centimeters distance from one another except the two central clips that were $2 \mathrm{~cm}$ from each other. Thus, the dis- tance between the stimulating cathode and the non-inverting recording electrode was $8 \mathrm{~cm}$, whereas the inter-electrode distance of the stimulating and recording pairs was $3 \mathrm{~cm}$. The spring of the alligator clips were removed to prevent compression of the tail. After anesthesia using an intramuscular solution of Xylazin Chlorhydrate and Ketamin, $0.2 \mathrm{ml} / 100 \mathrm{~g}$ weight, the animal was laid ventrally on the board. The tail was cleaned and degreased with $70 \%$ alcohol and fixed between the electrodes by us (Figure 1). The distal pair of electrodes was used for stimulation, the proximal pair for recording and the connected central pair as the ground electrode. Thus, an orthodromic sensory nerve conduction technique was used. Before each recording the tail was heated with a dichroic lamp to $32^{\circ} \mathrm{C}$, measured at a middle of the tail by an infrared thermometer (Doc Thermo; modelo n. HD - 11; Comdek Industrial Corp.). This work was approved by the local ethical committee for animal research.

The electrophysiological parameters studied were peakto-peak amplitude and onset latency nerve conduction velocity (NCV) of the sensory nerve action potential (SNAP). Measurements were taken 4 times and averaged together (Figure 1). The data was tabulated and analyzed using Microsoft Excel ${ }^{\circledR}$ spreadsheet. Amplitudes and NCV were summarized as means and standard deviations. Linear regression was used to model the data.
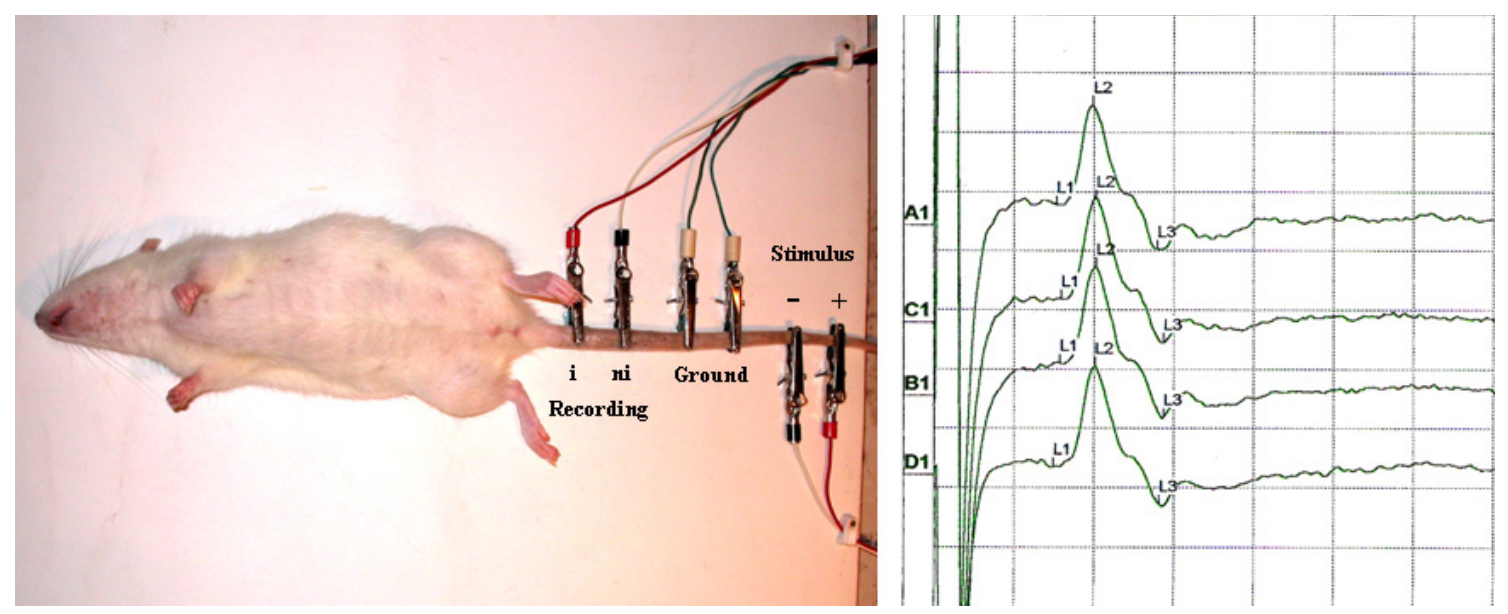

FIGURE 1 - The experimental setting is shown on the left side and the recording on the right side ( ni ). Non-inverting recording electrode (i) Inverting recording electrode.

( - ) Cathode stimulating electrode (+) Anode stimulating electrode

\section{Results}

The amplitude and the NCV of the caudal nerve SNAP increased linearly between the 8 th and the 15 th week of animal life, from $29 \pm 6 \mu \mathrm{V}$ to $85 \pm 13 \mu \mathrm{V}$ and from $34 \pm 3 \mathrm{~m} / \mathrm{s}$ to $44 \pm 4 \mathrm{~m} / \mathrm{s}$,
(Figure 2). The equations of linear regressions were as followed: Amplitude $(\mu \mathrm{V})=8.1 \times$ weeks $-34\left(\mathrm{R}^{2}=0.99\right)$ and $\operatorname{NCV}(\mathrm{m} / \mathrm{s})=1.2 \times$ weeks $+25\left(\mathrm{R}^{2}=0.86\right)$. 


\section{Amplitude $(\mu \mathrm{V})$}

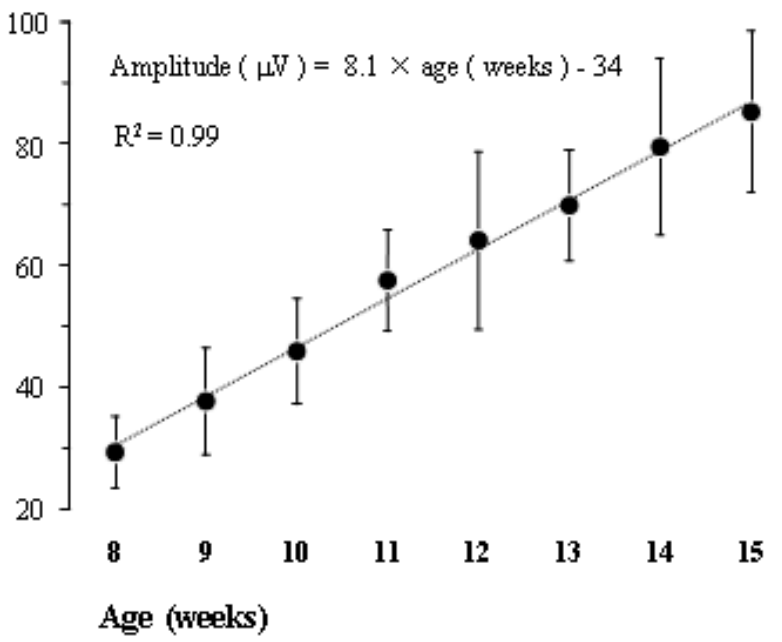

\section{$\operatorname{VCN}(\mathrm{m} / \mathrm{s})$}

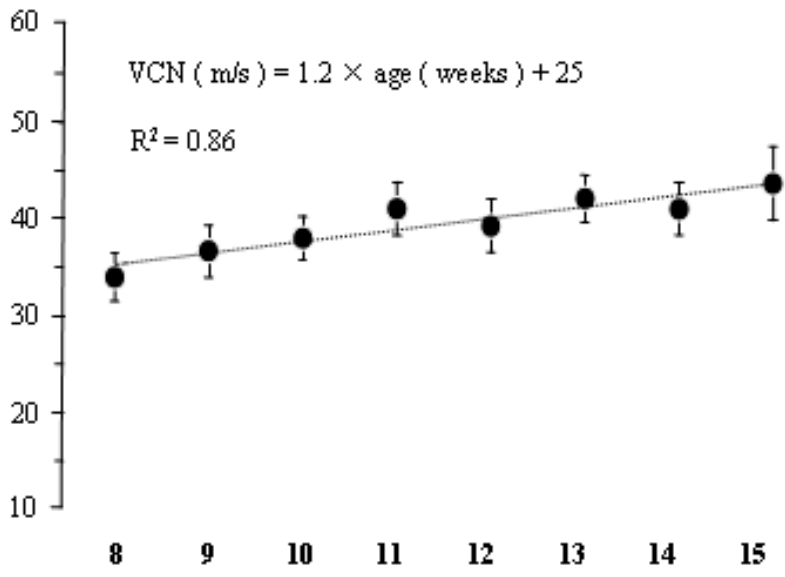

FIGURE 2 - Mean \pm standard deviation of the SNAP amplitudes (left side) and NCV (right side) between the 8th and the 15 th week of animal life. The equation of linear regression relating amplitude $(\mu \mathrm{V})$ or NCV $(\mu \mathrm{V})$ and age (weeks) and the squared correlation coefficient $\left(\mathrm{R}^{2}\right)$ is shown

\section{Discussion}

Both amplitude and NCV showed a linear increase proportionate to the age of the animal. This linear increase is probably due to the development of rats' peripheral nervous system itself. The mechanism of the conduction changes with aging is uncertain. It is believed that three mechanisms are involved on large diameter myelinated axons, interdonal legth and nodal events ${ }^{1}$.

There are not many electrophysiological studies of the caudal nerve of developing rats. Schmelzer and $\mathrm{Low}^{1}$, in their electrophysiological study on the effect of age on caudal nerve of Sprague-Dawley male rats, used a similar orthodromic technique but recorded with near the nerve fine steel needles. They observed that both the amplitude and the NCV were parabolic functions of age - they increased progressively until about 1 year and then declined. However, between the 8 th week and the 15 th week the function is virtually linear, as the quadratic component of the function is quite small ( 0.02 and 0.005 for NCV and amplitude respectively, per squared week).

During similar time frame Schmelzer and Low ${ }^{1} \mathrm{NCV}$ were about $4-8 \mathrm{~m} / \mathrm{s}$ faster then ours. One possible explanation for this small but consistent discrepancy is that we kept the temperature of the tail at $32^{\circ} \mathrm{C}$ whereas they kept it at $35^{\circ} \mathrm{C}$. As NCV increases a little more then $1 \mathrm{~m} / \mathrm{s} \mathrm{per}^{\circ} \mathrm{C}^{12}$ the difference in temperature fairly predicts the difference found in NCV.

Schmelzer and Low $^{1}$ amplitudes were about $50 \%$ smaller than our amplitudes. Amplitude decreases about $0.04 \mu \mathrm{V}$ per ${ }^{\circ} \mathrm{C}^{12}$, therefore the difference in tail temperature is not sufficient to explain the difference in NCV. Unfortunately, they did not report how the amplitudes were measured: baseline-to-peak or peak-to-peak. If it was baseline-to-peak it could explain why their amplitudes were smaller then our peak-to-peak amplitudes.

\section{Conclusion}

A non-invasive technique to perform sensory conduction studies in developing rats was described. Technique and data may be used as animal model in physiological and pathological studies.

\section{References}

1. Schmelzer JD, Low PA. Electrophysiological studies on the effect of age on caudal nerve of the rat. Exp Neurol. 1987;96:612-20.

2. Zollman PJ, Awad O, Schmelzer JD, Low PA. Effect of ischemia and reperfusion in vivo on energy metabolism of rat sciatic-tibial and caudal nerves. Exp Neurol. 1991;114:315-20.

3. Cruz MW, Correa RS, Puccioni-Sohler M, Novis SAP. Eletromiografia e potenciais evicados somatossensitivos na mielopatia pelo HTLV-I. Arq Neuropsiquiatr. 1998;56(4):756-62.

4. Murade ECM, Neto JSH, Avanzio O. Estudo da relação e da importância entre a semiologia clínica, tomografia axial computadorizada e eletroneuromiografia nas radiculopatias lombares. Acta Ortop Bras. 2002;10(4):18-25.

5. Sandrini FAL, Pereira-Junior ED, Gay-Escoda C. Rabbit facial nerve anastomosis with fibrin glue: nerbe conduction velocity evaluation. Rev Bras Otorrinoloaringol. 2007;73(2):196-201.

6 . Redding RW, Ingram JT, Colter SB. Sensory nerve conduction velocity of cutaneous afferents of the radial, ulnar, peroneal and tibial nerves of the dog: references values. Am J Vet Res. 1983;43:145-62.

7. Feitosa MM, Larsson MHMA, Ushikoshi, WS, Perri SHV. Padronização da determinação da velocidade de condução nervosa sensitiva dos nervos tibial e peroneal de cães clinicamente sadios, pela utilização de eletrodos de superfície. Arq Bras Med Vet Zootec. 2002;54(2):127-32.

8. Leal-cardoso JH, Matis-Brito BG, Lopes-Junior JEG, Viana-Cardoso KV, Sampaio-Freitas AB, Brasil RO, Coelho-de-Souza NA, Albuquerque AAC. Effects of estrangole on the compound action potencail of the rat sciatic nerve. Braz J Med Biol Res. 2004;37(8):1193-8. 
9. Martins RS, Siqueira MG, Silva CF, Godoy BO, Plese JPP Electrophysiologic assessment of regeneration in rat sciatic nerve repair resing suture of both technique. Arq Neuropsiquiatr. 2005;63(3-A):601-4 10. Malta J, Campolongo GD, Barros TEP, Oliveira RP. Eletromiografia aplicada aos músculos da mastigação. Acta Ortop Bras. 2006;14(2):106-7. 11. Low PA, Ward JD, Schmelzer JD, Brimijoin S. Ischemic conduction failure and energy metabolism in experimental diabetic neuropathy. Am J Physiol. 1985;248:457-62.

12. Leandri M, Lenadri S, Lunardi G. Effect of temperature on sensory and motor conduction of the rat tail nerves. Neurophysiol Clin. 2008;38:297-304.

Conflict of interest: none Financial source: none

\section{Correspondence:}

Juliana Netto Maia

Av. Rosa e Silva, 1205/302

52050-020 Recife-PE Brazil

Phone: (55-81)9999-9995

juliananettomaia@hotmail.com

Received: September 23, 2009

Review: November 19, 2009

Accepted: December 18, 2009

\section{How to cite this article}

Maia JN, Carvalho CC, Galvão MH, Silva AL, Mendes ACG, Moraes SRA, Lins OG. Eletrophysiological study of the caudal nerve on developing rats. Acta Cir Bras. [serial on the Internet] 2010 Mar-Apr;25(2). Available from URL: http://www.scielo.br/acb 